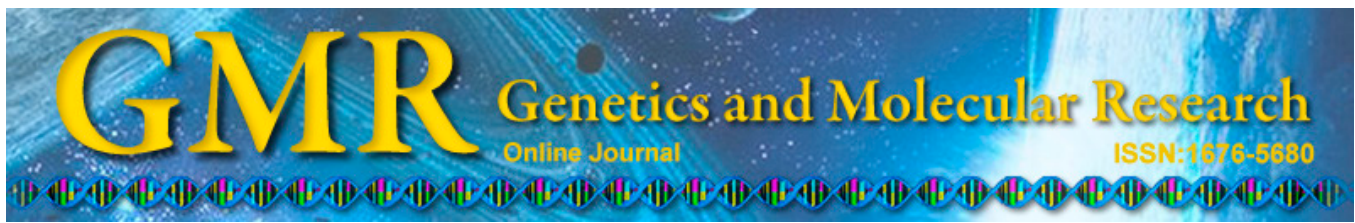

Short Communication

\title{
Effect of heat stress on heat-shock protein (Hsp60) mRNA expression in rainbow trout Oncorhynchus mykiss
}

\author{
H.N. Shi, Z. Liu, J.P. Zhang, Y.J. Kang, J.F. Wang, J.Q. Huang and \\ W.M. Wang \\ College of Animal Science and Technology, Gansu Agricultural University, \\ Lanzhou, Gansu, China \\ Corresponding author: Z. Liu \\ E-mail: liuz@gsau.edu.cn
}

Genet. Mol. Res. 14 (2): 5280-5286 (2015)

Received October 30, 2014

Accepted April 8, 2015

Published May 18, 2015

DOI http://dx.doi.org/10.4238/2015.May.18.20

\begin{abstract}
The enhanced expression of heat shock proteins (hsps) in organisms can be detected in response to many kinds of stressor. For fish, high temperature is an important stressor, and hsp expression is associated with differences in environmental temperature. In this study, rainbow trout (Oncorhynchus mykiss) that were accustomed to an aquatic temperature of $18^{\circ} \mathrm{C}$ were exposed to an elevated temperature $\left(25^{\circ} \mathrm{C}\right)$, and $h s p 60$ expression in the gill, liver, spleen, heart, and head kidney was quantified using real-time polymerase chain reaction in unstressed and heat-stressed animals. The fish responded to heat stress in a time- and tissue-specific manner. Cardiac $h s p 60 \mathrm{mRNA}$ levels were largely unchanged, and the greatest induction of hsp 60 in heat-stressed animals was recorded in the liver, suggesting that protein damage and the consequent requirement for the Hsp60 protein are probably greater in hepatic tissue. Therefore, fish must be provided with optimal
\end{abstract}


temperature conditions in order to realize their potential growth and maximize fish farm profits.

Key words: Hsp60; mRNA expression; Oncorhynchus mykiss; Heat stress

\section{INTRODUCTION}

Heat-shock proteins (Hsps) play an important role in thermal tolerance and acclimation, assist cells in recovery from stress, and promote cytoprotection. Hsps are highly conserved in their protein structures and amino acid sequences, and, based on their protein molecular weights, are grouped into families: Hsp100s, Hsp90s (83-90 kDa), Hsp70s (66$79 \mathrm{kDa}), \mathrm{Hsp} 60 \mathrm{~s}$, and small Hsps (15-30 kDa). There are two categories of Hsp: constitutive (or cognate) heat-shock proteins (hscs) and inducible heat-shock proteins (hsps). These are distinguished by their function and regulation. Inducible $h s p$ expression is regulated by heat-shock transcription factors (Pirkkala et al., 2001). In response to various stressors, including heat, most heat-shock transcription factors acquire DNA binding activity targeted to the heat-shock element (nGAAnnTTCn) in gene promoter regions, thereby modulating the transcription of $h s p$ genes, which results in the accumulation of Hsps (Pirkkala et al., 2001). Most inducible $h s p$ genes, including $h s p 60$, lack introns, and, as a result, hsp mRNAs can be rapidly translated into nascent proteins within minutes of exposure to a stressor (Iwama et al., 2004).

In recent years, the sequence information and expression of many $h s p$ s has been reported in many species, in particular the $h s p 90$ ( $h s p 90 a$ and $h s p 90 b$ ) and $h s p 70$ ( $h s c 70$ and hsp 70) gene families. For example, the $h s p 70$ family has been widely used as a biomarker, due to its rapid and significant up-regulation in response to a wide range of environmental stressors (Jonsson et al., 2006). Hsp60 is a stress-inducible, well-characterized chaperone that is mainly located in the mitochondria of eukaryotic cells (Martin et al., 1992; Soltys and Gupta, 1996). Hsp60 can elicit a potent proinflammatory response in cells of the innate immune system, and has therefore been hypothesized as a "danger signal" of stressed or damaged cells (Ohashi et al., 2000). Until now, most studies of hsp60 have focused on its gene sequence.

Fish represent an ideal organism in which to resolve the regulation and functional significance of Hsps. In addition, daily and seasonal temperature fluctuations have an important impact during the lifetime of individual fish. Consequently, responses to environmental stressors, such as temperature fluctuations, must be rapid and effective, so as to avoid detrimental health effects. Rainbow trout Oncorhynchus mykiss (Walbaum, 1792) is a widely distributed freshwater, cold-adapted aquaculture species, and has an upper lethal limit of around $26^{\circ} \mathrm{C}$ (Kaya, 1978). Due to habitat degradation, and possibly global and regional climate change, $O$. mykiss may experience temperatures approaching this upper lethal limit, particularly during the summer months. In this study, hsp60 mRNA expression in different tissues of unstressed, heat-stressed, and heat-stress recovering (HSR) O. mykiss was analyzed using real-time polymerase chain reaction (PCR). The purpose of this study was to ascertain whether Hsp60 plays a role in mediating hyperthermic effects. 


\title{
MATERIAL AND METHODS
}

\begin{abstract}
Animals
Forty $O$. mykiss individuals from the Donaldson strain, with the same genetic background, which were approximately 10 months old and had an average body mass of approximately $350 \mathrm{~g}$, were obtained from the same aquaculture net cages in the Liujiaxia Reservoir Fishing Ground, Gansu Province, northwest China. They were maintained in fiberglass tanks with oxygenated, running, well water $\left(18^{\circ} \pm 0.5^{\circ} \mathrm{C}\right)$ under a $12: 12$-h light:dark photoperiod. The trout were initially acclimated for 1 week prior to experimentation, and were fed commercial pellets to satiation twice per week. All of the experiments complied with institutional guidelines and were approved by the Animal Experimentation Ethics Committee of the Gansu Agricultural University, China.
\end{abstract}

\section{Heat stress}

Six groups (five fish in each) were compared in this study; prior to treatment, five fish were randomly netted from the tanks as the control group $(0 \mathrm{~h})$. The water temperature was then increased in recirculated, oxygenated water tanks (using a heater) at a rate of $2.5^{\circ} \mathrm{C} / \mathrm{h}$, to $25^{\circ} \mathrm{C} \pm 0.2^{\circ} \mathrm{C}$. After the point when the temperature reached $25^{\circ} \mathrm{C}$, four other groups were sampled after $2,4,8$, or $12 \mathrm{~h}$ of $25^{\circ} \mathrm{C}$ heat-shock exposure. A final group of fish was returned to a tank with recirculated water at $18^{\circ} \mathrm{C}$ for recovery, and samples were taken after $6 \mathrm{~h}$ (HSR). During the experiment, 10 fish died after 2-12 h of exposure to heat shock.

\section{Sampling}

The animals were quickly captured and euthanized, after being anaesthetized by immersion until being sedated in a clove-essence solution. Tissue samples from the liver, head kidney, spleen, heart, and gill were removed and transferred to 2-mL storage tubes, which were immediately frozen in liquid nitrogen and stored at $-80^{\circ} \mathrm{C}$ until analysis.

\section{Total RNA extraction and reverse transcription reaction}

Total RNA was isolated from each tissue sample using TRIzol reagent (TransGen, Beijing, China), according to the manufacturer protocol. The final RNA pellet was dissolved in $30 \mu \mathrm{L}$ RNase-free water. RNA concentration and quality were verified using a spectrophotometer (Implen, NanoPhotometer ${ }^{\circledR}$ Pearl 360, Germany) at an optical density of $260 \mathrm{~nm}$ and RNA gel electrophoresis, respectively. All of the samples were then stored at $-80^{\circ} \mathrm{C}$.

First-strand cDNA was synthesized from $1 \mu \mathrm{g}$ total RNA using a PrimeScript ${ }^{\mathrm{TM}}$ reverse transcriptase reagent kit. Genomic DNA was eliminated by treatment with a gDNA Eraser (TaKaRa, Dalian, China) for 2 min at $42^{\circ} \mathrm{C}$. The kit included a reagent component that inhibited DNA degradation activity. The reverse transcription reactions proceeded for $15 \mathrm{~min}$ at $37^{\circ} \mathrm{C}$ and were then inactivated for $5 \mathrm{~s}$ at $85^{\circ} \mathrm{C}$. All of the cDNAs were stored at $-20^{\circ} \mathrm{C}$ until use. 


\section{Real-time PCR}

Cross-species quantitative PCR (qPCR) primers for $h s p 60$ were designed based on consensus sequences in Salmo salar L. 1758 orthologs in GenBank (accession No. AY049960.1). O. mykiss $\beta$-actin (GenBank accession No. AB196465.1) was used as a reference gene (Ojima et al., 2005). The primer sequences are presented in Table 1.

Table 1. Primers used for the real-time polymerase chain reaction.
\begin{tabular}{lllcc}
\hline Gene & Accession No. & Primer sequence & Nucleotide position & Product length (bp) \\
\hline hsp60 & AY049960.1 & F: 5'-ATGGTAGAGAAGGGCATCATTG-3' & $367-458$ & 92 \\
$\beta$ - actin & AB196465.1 & $\begin{array}{l}\text { R: 5'-TCAGCAGTGGAGAGAAGGGA-3' } \\
\text { F:-TGGGGCAGTATGGCTTGTATG-3' }\end{array}$ & $1624-1788$ & 165 \\
\hline
\end{tabular}

$\mathrm{F}=$ forward primer; $\mathrm{R}=$ reverse primer.

cDNAs were used as templates for the amplification of the reference $(\beta$-actin) and target (hsp60) genes. The qPCRs used $10 \mu \mathrm{L} \mathrm{SYBR}^{\circledR}$ Premix Ex Taq ${ }^{\mathrm{TM}} \mathrm{II}$ (TaKaRa), $0.4 \mu \mathrm{L}$ of each primer $(10 \mu \mathrm{M}), 7.2 \mu \mathrm{L}$ RNase-free $\mathrm{ddH}_{2} \mathrm{O}$, and $2 \mu \mathrm{L}$ cDNA template $(<100 \mathrm{ng})$. qPCRs of $20 \mu \mathrm{L}$ were run on 96-well plates on a LightCycler ${ }^{\circledR} 480$ Instrument II (Roche, Switzerland), with $30 \mathrm{~s}$ initial denaturation at $95^{\circ} \mathrm{C}$, followed by 40 cycles at $95^{\circ} \mathrm{C}$ for $5 \mathrm{~s}, 50^{\circ} \mathrm{C}$ for 20 $\mathrm{s}$, and $72^{\circ} \mathrm{C}$ for $15 \mathrm{~s}$. A melting curve analysis $\left(95^{\circ} \mathrm{C}\right.$ for $5 \mathrm{~s}$ and $60^{\circ} \mathrm{C}$ for $\left.15 \mathrm{~s}\right)$ was performed after each qPCR run in order to verify the amplification specificity, which was indicated by single peaks.

\section{Statistical analysis}

qPCR cycle thresholds $(\mathrm{Ct})$ were calculated as the average of the triplicates (per tissue sample) for both the target and reference genes. hsp60 mRNA expression was measured in each individual specimen, and was normalized to the $\beta$-actin gene. $\beta$-actin expression exhibited no response to temperature $(\mathrm{N}=3$ individuals) in preliminary experiments (data not shown). These experiments also indicated that the amplification efficiencies of $\beta$-actin and hsp60 did not violate the assumptions of the $\Delta \Delta \mathrm{Ct}$ method. Relative mRNA detection was calculated using the formula $2^{-\Delta \mathrm{Ct}}$ (Zhang et al., 2014), and the results are reported as means $\pm \mathrm{SE}$ $(\mathrm{N}=5)$. One-way analysis of variance (ANOVA) followed by the Duncan multiple range test at $\mathrm{P}<0.05$ was performed using the SPSS 18.0 software (IBM, Armonk, NY, USA), in order to compare $h s p 60$ mRNA levels between different tissues and experimental groups.

\section{RESULTS}

hsp60 expression in the liver and head kidney increased during a 4-8-h exposure to elevated water temperatures, before decreasing. Expression levels in all of the tissues, except the liver, returned to the level of the control group (unstressed, $0 \mathrm{~h}$ ) in HSR fish. After $8 \mathrm{~h}$ of heat stress, $h s p 60$ mRNA levels in the gill, liver, and head kidney were significantly higher than those in the control group by approximately 1.88-, 6.95-, and 3.05-fold, respectively $(\mathrm{P}<0.05)$, and after $12 \mathrm{~h}$ by approximately $2.43-, 4.14-$, and 2.10 -fold, respectively $(\mathrm{P}<0.05$; Figure 1$)$. 


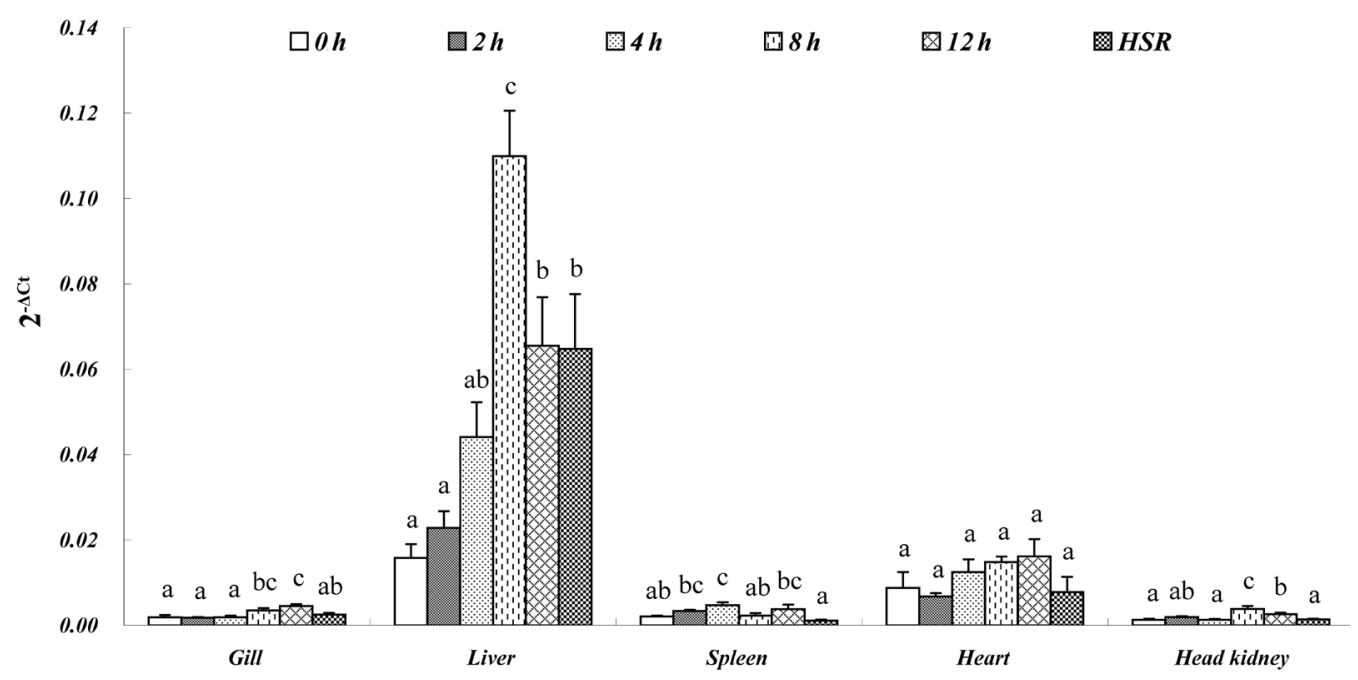

Figure 1. Expression level changes of $H s p 60 \mathrm{mRNA}$ in different tissues of unstressed, heat-stressed, and heat-stress recovering (HSR) fish. Different letters mean significant differences $(\mathrm{P}<0.05)$.

In addition, $H s p 60$ expression levels in the liver were significantly higher in the HSR fish than in the control group (4.10-fold, $\mathrm{P}<0.05)$. In the spleen, significantly higher levels of $h s p 60$ mRNA than in the control group were only found after $4 \mathrm{~h}$ of heat stress $(2.26$-fold, $\mathrm{P}<0.05)$. In contrast, mRNA levels of cardiac $h s p 60$ were largely unaffected by heat stress $(\mathrm{P}>0.05)$.

Therefore, cardiac $h s p 60$ mRNA levels were mainly unaffected by thermal stress, and the highest induction of $H s p 60$ was recorded in the liver. hsp60 expression in the liver was significantly higher after heat stress than in the other tissues investigated $(\mathrm{P}<0.05$; Figure 2$)$.

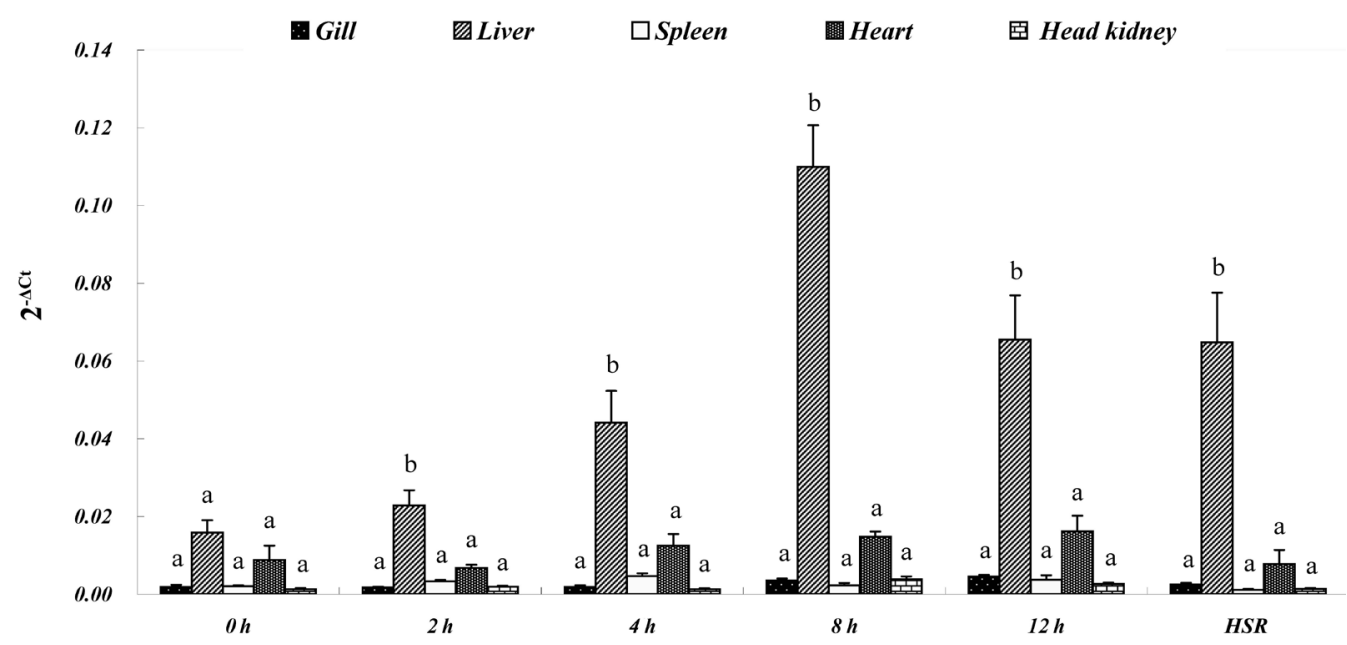

Figure 2. Comparison of Hsp60 mRNA expression levels in different tissues at similar time points. HSR = heatstress recovering fish. Different letters mean significant differences $(\mathrm{P}<0.05)$. 


\section{DISCUSSION}

In this study, a prominent induction of $h s p 60$ was detected in the liver, whereas levels of heart $h s p 60$ were largely unaffected. The tissue-specific differences in $h s p 60$ expression found in this study are similar to those observed for hsp 70 expression in carp, Cyprinus carpio L. 1758 (Wang et al., 2007). Similarly, tissue-specific $h s p 70$ expression was reported in the killifish Fundulus heteroclitus (L. 1766) (Koban et al., 1991), fathead minnow Pimephales promelas Rafinesque 1820 (Dyer et al., 1991), brown trout Salmo trutta L. 1758 (Schmidt et al., 1998), and sea lamprey Petromyzon marinus L. 1758 (Wood et al., 1999). The fact that stress responses differ between tissues supports the hypothesis that the thermal limits of an organism are governed by certain tissues more than others (Dyer et al., 1991). In this study, a prominent induction of $h s p 60$ synthesis was clearly apparent in the liver. Previous studies that have examined the subcellular localization of Hsp60 in the rat liver found that Hsp60 reactivity is present in peroxisomes, which are sub-cellular organelles that are involved in a variety of oxidative reactions (Alberts et al., 1994). Similarly, significant inductions of $h s p 90$ have been identified in the livers of juvenile and mature O. mykiss (Rendell et al., 2006). In fish and other vertebrates, the liver performs several crucial functions, including detoxification, metabolism, bile secretion, immune defense, and hormone synthesis. In the present study, hepatic $h s p 60$ expression exceeded that of the other tissues investigated, suggesting that the extent of protein damage and subsequent requirement for the Hsp60 protein is probably greater in the liver than in other tissues of $O$. mykiss. Hsp60 may play a significant role in dealing with heat-induced damage in the liver. In addition, $6 \mathrm{~h}$ after HSR, hsp 60 levels in the liver did not return to the level at $0 \mathrm{~h}$, unlike in the other tissues, suggesting that hepatic damage resulting from thermal stress is not readily restored.

Gill hsp60 levels were moderately up-regulated, and then returned to baseline after HSR. The gill is a crucial organ for respiratory, osmoregulatory, excretory, and branchial functions, and is highly sensitive to environmental stressors (Wang et al., 2007). Because of their constant exposure to temperature fluctuations, gill cells increase their resistance to stress by up-regulating the expression of $h s p 60$. Similarly, elevated Hsp70 concentrations in the gill have been reported in C. carpio (Wood et al., 1999).

The spleen and kidney are major lymphoid organs in fish (Mulero et al., 2007), and have important functions in implementing immune responses and maintaining a stable internal environment. In this study, spleen and head kidney hsp60 expression was consistently lower than that in liver tissue during heat stress. Elibol-Flemming et al. (2009) demonstrated that splenic $h s p 70$ expression is significantly lower than in the liver during acute-phase cell-stress responses. This suggests that the spleen and head kidney might have adapted to some chronic stressors, or that there may be other regulatory mechanisms involved.

A lower $h s p 60$ response was observed in cardiac tissue than in the gill, liver, spleen, or head kidney. In vertebrates, blood circulation must be modulated to satisfy the metabolic demands of tissues. In ectothermic animals, including fish, metabolic rate is strongly dependent on the ambient temperature (Korajoki and Vornanen, 2014). Wang et al. (2007) reported that mild or moderate heat shock results in elevated $h s p 70$ levels in the heart tissue of C. carpio. The results of the present study suggest that $O$. mykiss may not have needed to adjust levels of cardiac $h s p 60$ when subjected to heat shock at $25^{\circ} \mathrm{C}$. The absence of significant $h s p 60$ upregulation in heart tissue may also be related to the anatomical location and function of this organ, to the fish species and size, and to the environmental conditions. 


\section{ACKNOWLEDGMENTS}

Research supported by the National Natural Science Foundation of China (\#31460687) and the Fundamental Research Funds for the University of Gansu Province (2013).

\section{REFERENCES}

Alberts B, Bray D, Lewis J, Raff M, et al. (1994). Molecular Biology of the Cell. 3rd edn. Garland Science, New York.

Dyer SD, Dickson KL, Zimmerman EG and Sanders BM (1991). Tissue-specific patterns of synthesis of heat-shock proteins and thermal tolerance of the fathead minnow (Pimephales promelas). Can. J. Zool. 69: 2021-2027.

Elibol-Flemming B, Waldbieser GC, Wolters WR, Boyle CR, et al. (2009). Expression analysis of selected immunerelevant genes in channel catfish during Edwardsiella ictaluri infection. J. Aquat. Anim. Health 21: 23-35.

Iwama GK, Afonso LOB, Todgham A, Ackerman P, et al. (2004). Are hsps suitable for indicating stressed states in fish? J. Exp. Biol. 207: 15-19.

Jonsson H, Schiedek D, Goksøyr A and Grøsvik BE (2006). Expression of cytoskeletal proteins, cross-reacting with antiCYP1A, in Mytilus sp. exposed to organic contaminants. Aquat. Toxicol. 78: S42-S48.

Kaya CM (1978). Thermal resistance of rainbow trout from a permanently heated stream and of two hatchery strains. Prog. Fish Cult. 40: 138-142.

Koban M, Yup AA, Agellon LB and Powers DA (1991). Molecular adaptation to environmental temperature: heat-shock response of the eurythermal teleost Fundulus heteroclitus. Mol. Mar. Biol. Biotechnol. 1: 1-17.

Korajoki H and Vornanen M (2014). Species- and chamber-specific responses of $12 \mathrm{kDa}$ FK506-binding protein to temperature in fish heart. Fish Physiol. Biochem. 40: 539-549.

Martin J, Horwich AL and Hartl FU (1992). Prevention of protein denaturation under heat stress by the chaperonin Hsp60. Science 258: 995-998.

Mulero I, García-Ayala A, Meseguer J and Mulero V (2007). Maternal transfer of immunity and ontogeny of autologous immunocompetence of fish: A mini review. Aquaculture 268: 244-250.

Ohashi K, Burkart V, Flohè S and Kolb H (2000). Cutting edge: heat shock protein 60 is a putative endogenous ligand of the Toll-like receptor-4 complex. J. Immunol. 164: 558-561.

Ojima N, Yamashita M and Watabe S (2005). Quantitative mRNA expression profiling of heat-shock protein families in rainbow trout cells. Biochem. Biophys. Res. Commun. 329: 51-57.

Pirkkala L, Nykanen P and Sistonen L (2001). Roles of the heat shock transcription factors in regulation of the heat shock response and beyond. FASEB J. 15: 1118-1131.

Rendell JL, Fowler S, Cockshutt A and Currie S (2006). Development-dependent differences in intracellular localization of stress proteins (hsps) in rainbow trout, Oncorhynchus mykiss, following heat shock. Comp. Biochem. Phys. D 1: 238-252.

Schmidt H, Posthaus H, Busato A, Wahli T, et al. (1998). Transient increase in chloride cell number and heat shock protein expression (hsp70) in brown trout (Salmo trutta fario) exposed to sudden temperature elevation. Biol. Chem. 379: 1227-1234.

Soltys BJ and Gupta RS (1996). Immunoelectron microscopic localization of the 60-kDa heat shock chaperonin protein (Hsp60) in mammalian cells. Exp. Cell Res. 222: 16-27.

Wang Y, Xu J, Sheng L and Zheng Y (2007). Field and laboratory investigations of the thermal influence on tissue-specific Hsp70 levels in common carp (Cyprinus carpio). Comp. Biochem. Phys. A 148: 821-827.

Wood LA, Brown IR and Youson JH (1999). Tissue and developmental variations in the heat shock response of sea lampreys (Petromyzon marinus): effects of an increase in acclimation temperature. Comp. Biochem. Phys. A 123: $35-42$.

Zhang LL, Sun CF, Ye X, Zou SM, et al. (2014). Characterization of four heat-shock protein genes from Nile tilapia (Oreochromis niloticus) and demonstration of the inducible transcriptional activity of Hsp70 promoter. Fish Physiol. Biochem. 40: 221-233. 